\title{
Belief, Inquiry, and Meaning: Integrasi-Interkoneksi Elemen Dialog Teori Filsafat Kontemporer dengan Elemen Dialog Level Praksis Kepustakawanan
}

\author{
Mukhlis \\ Perpustakaan Universitas Janabadra \\ email: mukhlissukajogja@gmail.com
}

\begin{abstract}
Abstrak
Kesadaran akan perlunya integrasi-interkoneksi antara ilmu pengetahuan (science), dengan nilai-nilai moral (social-humanities), dan agama (religion) akan muncul manakala manusia semakin sadar bahwa ilmu pengetahuan tidak dapat berdiri/berjalan sendiri sehingga salah satu teori filasat kontemporer yang relevan dengan hal tersebut yakni tiga konsep utama (Belief, Inquiry, and Meaning) sebagai isu kunci. Situasi tersebut berkorelasi dengan kegiatan kepustakawanan, karena hal tersebut menyangkut dua hal, yakni mengelola informasi menjadi pengetahuan, serta kemampuan untuk melayankannya kepada para pemustaka. Dinamika atau dinamisasi teori disebabkan oleh faktor pengetahuan (science) yang dimunculkan dari dan oleh manusia itu sendiri yang memiliki keyakinan (belief) dalam hal mencari, dan menginvestigasi (inquiry) sehingga membentuk sebuah perilaku untuk memaknai (meaning) sesuatu, baik individu maupun sosial (social-humanities) terhadap seuatu informasi, sehingga tiga konsep tersebut mampu berdialog (berkomunikasi; bertuegur-sapa) dengan elemen dialog kepustakawanan khususnya pada tataran praksis. Dialog tersebut ditemukan pada titik temu pada elemen informasi yang bermuara pada pengetahuan (science).
\end{abstract}

\section{A. PENDAHULUAN}

Dinamika yang terus berkembang sehingga melahirkan berbagai paradigma baru dalam sektor ilmu pengetahuan, diantaranya adalah ilmu perpustakaan dan informasi yang tak luput mengalami dan mengikuti perkembangan tersebut, terutama dari segi epistemologinya. Jika menyimak lebih jauh bahwa epistemologi, atau teori tentang pengetahuan adalah merupakan cabang dari ilmu filsafat. Terkait dengan hal tersebut, Pendit (2003) menyebutkan bahwa epistemologi atau teori tentang pengetahuan (dalam konsepsi tersebut) yang berurusan dengan pembahasan mengenai sifat, asal usul, lingkup, dan batas dari pengetahuan manusia, pandangan-pandangan yang mendasari kelahirannya, serta bagaimana metode untuk mendapatkannya. Berangkat dari konsepsi tersebut, dapat disimpulkan bahwa dinamika kehidupan disebabkan oleh faktor pengetahuan (science) yang dimunculkan dari dan oleh manusia itu sendiri, sehingga kedudukan manusia sebagai individu dan anggota masyarakat (social-humanities) dalam satu struktur kesatuan yang senada dalam konsepsi agama (religion). Dengan demikian manusia adalah makhluk individu yang memasyarakat sekaligus makhluk sosial yang mengindividu. Sehingga manusia akan semakin sadar bahwa ilmu pengetahuan tidak dapat berjalan sendiri tetapi berkembang secara dinamis melalui perpaduan dari elemen dialog dari berbagai paradigma yang melekat padanya.

Kesadaran akan perlunya integrasiinterkoneksi antara ilmu pengetahuan (science), dengan nilai-nilai moral (social-humanities), dan agama (religion) akan muncul manakala manusia semakin sadar bahwa ilmu pengetahuan tidak dapat berdiri/berjalan sendiri. Seperti yang disebutkan oleh Barbour dalam (Khuza'i, 2007) bahwa salah satu fungsi ilmu pengetahuan adalah untuk mendeskripsikan, tentu saja dalam hal ini menggunakan alat ukur yang memiliki standar keilmuan. Menurut Rodliyah (2007:47), bahwa tinjauan kritis (terhadap aspek teoretis ilmu) memang harus berujung pada aspek praksis (aksi 
nyata) yang tercermin dalam bentuk tanggung jawab, hidup yang baik dan bersih. Jadi aspek studi dan aksi dari dimensi moral dan agama ibarat pendulum yang selalu bergoyang ke kanan dan ke kiri (dua sisi). Jika ia bergoyang ke sisi studi (kajian), maka ia akan mempertajam wawasan berfikir dan semangat bertindak, sekaligus mengurangi kesan karikaturis. Jika bergoyang ke sisi action dan praxis, maka pengetahuan akan moralitas itu teraplikasi dalam kehidupan sehari-hari. Pendulum itu sealalu bergerak ke kedua sisi supaya tidak beku, tetapi kreatif-inovatif dan emansipatoris.

Situasi tersebut di atas, jika dikaitkan ke dalam ranah kepustakawanan, maka hal tersebut juga bergerak pada dua sisi. Misalnya jika mengarah ke sisi studi (kajian), maka orang-orang yang berkecipung dalam dunia kepustakawanan akan mempertajam wawasan berpikir dan semangat bertindaknya. Wawasan berpikir adalah sebuah keharusan yang perlu dimiliki oleh setiap insan pengelola informasi (pustakawan), karena hal tersebut menyangkut dua hal, yakni mengelola informasi menjadi pengetahuan, serta kemampuan untuk melayankannya kepada para pemustaka. Hal ini lah yang nantianya akan digiring ke arah action dan praxis.

Salah satu konsep filsafat kontemporer yang populer dibicarakan yakni Belief, Inquiry, and Meaning. Berangkat dari hal tersebut di atas, maka penulis berasumsi bahwa terdapat keterkaitan titik temu pada konsepsi tersebut melalui penjabaran masing-masing elemen dialog teori. Sejauh pengamatan penulis, belum terdapat kajian atau penelitian yang memfokuskan diri untukmengamati dimana letak titik temu pada kedua disiplin ilmu tersebut, sehingga dibutuhkan kajian mendalam untuk mengintegrasi-interkoneksikan elemen dialog filsafat kontemporer dengan elemen dialog praksis kepustakawanan. Oleh karena itu tulisan ini diharapkan untuk memberikan gambaran dengan pasti letak titik temu konsepsi dari masing-masing bidang keilmuan tersebut.

\section{B. KAJIAN TEORI}

\section{Konvergensi Konsep}

Konsep filsafat kontemporer (yang menjadi isu kunci) ada tiga konsep yakni Belief, Inquiry, and Meaning. Konvergensi konsep ini akan dijelaskan secara beriringan dengan konsepsi kepustakawanan, penjabarannya sebagai berikut.

\section{Hakikat Keyakinan}

Keyakinan (belief), merupakan pernyataan yang tegas mengenai preposisi yang dinilai benar dan merupakan persiapan secara sadar dari seseorang untuk berbuat dengan cara yang pasti (Khuza'i, 2007). Konsepsi lain yang terkait dengan hakikat keyakinan disebutkan bahwa keyakinan adalah sikap mental atas dasar kepastian bahwa ada kebenaran, tetapi kebenaran yang diselidiki sendiri (Soetriyono, 2007). Perbedaan utama antara keraguan dan keyakinan adalah pada tataran praksis, karena keyakinan akan membimbing seseorang untuk membentuk tindakannya. Seperti halnya dijelaskan oleh Munitz (1981) bahwa:

"a belief is the assertion of a proposition a person holds to be true, it is that upon which a person is consciously prepared to act in a certain definite way, it makes a habit of mind, it is the opposite of a state of doubt".

Terjemahan bebas sebagai berikut: "keyakinan adalah pernyataan dari proposisi seseorang menjadi kenyataan, dimana seseorang secara sadar siap untuk bertindak dengan cara tertentu, kebalikan dari keyakinan adalah keraguan".

Seseorang yang yakin, pasti akan berbeda dengan orang ragu. Setidaknya terdapat dua hal, yakni: feeling and behavior. Oleh karena itu, menurut Choir (2009), bahwa orang yang selalu ragu akan merasa tidak nyaman dan akan berupaya untuk menghilangkan keraguan tersebut untuk 
menemukan sebuah keyakinan yang benar. Dengan ilmu pengetahuan, akan terlahir sebuah keyakinan pada diri seseorang. Keyakinan tersebut akan mengantarkannya untuk terus mencari dan mencari hal-hal yang sifatnya baru yang disebut dengan informasi.

Konsep informasi dalam konteks ilmu perpustakaan yakni bagaimana informasi (information, informare) merujuk kepada pengembangan konsep pustaka (merujuk ke institusi sosial-budaya, yakni membaca adalah bermanfaat, penting, dan perlu dilakukan, sehingga esensinya tidak dapat terpisahkan dengan makna atau konsep informasi) yang semula hanya berkaitan dengan membaca (teks/tulisan) menjadi ke segala hal (realita) yang dapat disimbolkan dan berkaitan dengan membaca (teks/tulisan) menjadi ke segala hal (realita) yang dapat disimbolkan dan dikode (coded) menjadi data untuk dikomunikasikan antar manusia melalui peralatan biologis, mekanik, maupun elektronik. Sama halnya dengan pustaka, konsep dan makna informasi amat berkaitan dengan niat sebuah masyarakat untuk cerdas secara bersama, menghargai kebutuhan dan kepentingan semua orang akan data dan pengetahuan, serta menjamin kehidupan yang demokratis dalam berpengetahuan (Pendit, 2003). Pendapat serupa bahwa di dunia perpustakaan, eksistensi informasi menjadi garapan utama untuk kepentingan peningkatan kualitas manusia pada umumnya sehingga melalui metode penyebarluasan informasi (dissemination of information) diharapkan dapat memberikan kebebasan serta akses kepada masyarakat terkait dengan informasi yang dikelola oleh perpustakaan (Yusuf, 2010).

Dari berbagai konsepsi tersebut di atas, maka tidak dapat dipungkiri bahwa seluruh aspek kehidupan masyarakat tidak terlepas dari informasi, sehingga keberadaannya diharapkan menunjang pola hidup yang lebih baik dan menciptakan masyarakat yang literer atau melek terhadap informasi. Tentu saja untuk memenuhi hal tersebut, perpustakaan dan pustakawan memiliki peran yang cukup besar di dalamnya mengingat era sekarang perkembangan informasi pun tidak dapat dibendung sehingga melahirkan ledakan informasi (information explosive) yang cukup serius. Harapannya perpustakaan dapat menjadi garda untuk menanggulangi hal tersebut, mengingat eksistensinya sebagai pengelola pengetahuan (preservator of knowledge) sehingga perpustakaan harus mampu mengelola dan mengemas ulang informasi (information repackaging) yang berseliweran menjadi suatu pengetahuan kemudian menyebarluaskan. Terlepas dari hal tersebut, maka pustakawan sebagai salah satu aktor intelektual di perpustakaan dituntut untuk berperan aktif di dalamnya, mengingat eksistensinya sebagai penyedia dan pengelola informasi (information provider) maka pustakawan harus mampu tampil trampil dalam menagani situasi tersebut, sehingga informasi dapat tersalurkan dengan baik.

\section{Penyelidikan/Investigasi (Inquiry)}

"Living doubt is the life of investigation". Konsepsi yang dikemukakan oleh Munitz (1981) menggambarkan bahwa keraguan dalam kehidupan akan melahirkan investigasi/ penyelidikan dalam hidup, karena hidup merupakan sebuah teka-teki atau misteri. Oleh karena itu (Marzano, 2000) menyebutkan bahwa Investigasi adalah proses "dari membuat dan menguji berbagai hipotesis mengenai kejadian-kejadian masa lalu, masa sekarang dan masa depan". Investigasi mirip dengan pertanyaan percobaan dalam beberapa hal, tetapi berbeda metode dan jenis buktinya. Orang-orang tidak secara langsung mengamati dan mengumpulkan data dalam sebuah investigasi. Mereka mendapatkan informasi dari berbagai tulisan dan pengalaman orang lain. Berbagai kesimpulan dari sebuah investigasi ditentukan berdasar pada kekuatan dan logika argument 
mereka.

Dengan begitu, kegiatan investigasi tidak akan pernah terlepas dari informasi. Perpustakaan merupakan salah satu penyedia serta pengelola informasi. Oleh karena itu, kegiatan investigasi tersebut merupakan bagian dari hiruk-pikuk kegiatan di perpustakaan mengingat eksistensinya sebagai pengelola pengetahuan (preservator of knowledge). Salah satu contoh kegiatan investigasi yang umumnya dilakukan dalam dunia kepustakawanan adalah yang berkaitan dengan penggunaan sistem informasi yang terbagi dalam berbagai jenis perilaku, oleh (Wilson, 2000) dibagi menjadi empat jenis yakni:

a. Perilaku Informasi (Information Behavior)

Dimaknai dengan keseluruhan prilaku manusia yang berkaitan dengan sumber informasi, seperti prilaku pencarian dan pemanfaatan informasi, baik aktif maupun pasif.

b. Perilaku Penemuan Informasi (Information Seeking Behavior)

Dimaknai dengan upaya dalam menemukan informasi untuk tujuan tertentu yang didasari dengan kebutuhan dalam tujuan tertentu.

c. Perilaku Pencarian Informasi (Information Searching Behavior)

Dimaknai dengan perilaku pada tataran level mikro yang berupa perilaku seseorang saat melakukan interaksi dengan sistem informasi, baik dengan sistem (komputerisasi) atau pada tingkat intelektual dalam menyeleksi berbagai informasi dan memilih sesuai dengan kebutuhannya.

d. Perilaku Penggunaan Informasi (Information Use Behavior)

Dimaknai dengan tindakan fisik maupun tindakan mental seseorang saat melakukan penggabungan antara informasi yang ditemukan dengan pengetahuan dasar yang dimilikinya.
Dari konsepsi tersebut di atas, oleh Pendit (2014) dijelaskan bahwa hanya informasi tentang pengetahuan itulah yang dapat direkam dan dipakai oleh orang lain, dan informasi tidak lain adalah wakil (surrogate) dari pengetahuan yang komplit. Oleh karena itu, terdapat kesinambungan antara konsepsi pemikiran filsafat dengan ranah kepustakawanan, dilihat dari aspek investigasinya, mengingat pekerjaannya yang melayani para pemustaka untuk mendapatkan informasi dari berbagai tulisan dan sumber-sumber informasi lainnya di perpustakaan.

\section{Makna (Meaning)}

Teori tentang makna (Meaning) atau pemaknaan yaitu teori makna yang operatif, sehingga intinya konsep mengenai sebuah objek adalah seperangkat keseluruhan kebiasaan yang melibatkan objek tertentu (Khuza'i, 2007). Pierce memuat teori makna yang operasional, sehingga suatu kata merujuk pada suatu objek yang merujuk pada kata tersebut-, makna rasional suatu kata terletak pada hubungan logis suatu kata dengan kebiasaaan dalam kehidupan. Sehinga asosiasi kebermaknaan suatu pernyataan harus bisa membuktikan benar salahnya secara eksperimental.

Seperti dijelaskan oleh Munitz (1981) bahwa konsep adalah tanda umum atau ekspresi yang disebut sebagai simbol. Bentuk logis dari pernyataan suatu aturan atau hukum atau kebiasaan dengan pernyataan "kapan saja-------maka------"atau "if----------,then----". Seperti sebuah ungkapan, "Batu itu berat", konsep umum "Berat" digunakan dalam menetapkan bahwa batu itu memiliki kandungan. Jika sesuatu itu "berat"., ia akan memperlihatkan kandungan akibat yang diindra secara pasti. Untuk menyatakan batu itu berat, maka ditetapkan dengan predikat "berat", jika seseorang menggunakan pemberlakukan khusus dengan predikat tertentu akibat yang dapat diindra 
Belief, Inquiry, and Meaning: Integrasi-Interkoneksi ... (Mukhlis)

dapat diobservasi (Khuza'i, 2007).

Makna dalam konteks kepustakawanan adalah maknayanglebihdalamyang dapatmenjelaskansifat khusus tentang makna itu sendiri. Oleh sebab itulah sekali lagi dinyatakan perlunya pendekatan filosofis guna menerangkan makna kepustakawanan. Hal ini senada dengan penjelasan Blasius (2013) bahwa kata kepustakawanan sendiri memang menjadi kata turunan dari kata pustakawan. Kaidah Bahasa Indonesia menerangkan arti afiks ke-an. Penurunan nomina dengan ke-an dengan sumber nomina artinya merujuk pada: keabstrakan atau hal mengenai sesuatu. Sehingga kepustakawanan adalah keabstrakan atau hal mengenai pustakawan. Dengan demikian kepustakawanan mempunyai lingkup makna yang luas. Kepustakawanan dapat berarti mulai dari persyaratan menjadi pustakawan, karakter pustakawan, dan lain sebagainya sampai ke idealisme dari pustakawan. Secara skematis kekerabatan lima kata itu dapat dilukiskan dengan diagram berikut.

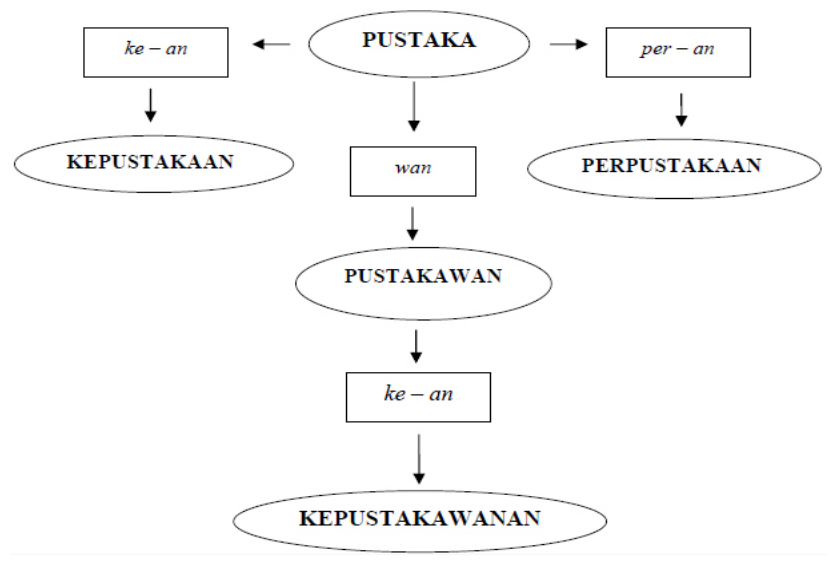

Sumber: (Sudarsono, 2013)

Dalam diagram diatasjelas bahwatitikpusatnya adalah pustakawan meski awal situasi adalah dari pustaka. Oleh karena itu, kepustakawanan mempunyai lingkup makna yang luas dalam konteks ini. Pustakawan dapat dimaknai dengan mengacu pada Undang-Undang Nomor 43, Tahun 2007 tentang Perpustakaan (UU 43, Th 2007). Menurut UU tersebut bahwa pustakawan adalah: seseorang yang memiliki kompetensi yang diperoleh melalui pendidikan dan/atau pelatihan kepustakawanan serta mempunyai tugas dan tanggung jawab untuk melaksanakan pengelolaan dan pelayanan perpustakaan. Dalam konteks ini, terdapat dua makna pada pustakawan yakni pendidikan serta tugas dalam bidang perpustakaan. Sedangkan perpustakaan dapat dimaknai dengan mengacu pada Undang-Undang Nomor 43, Tahun 2007 tentang Perpustakaan (UU 43, Th 2007 pasal 1). Menurut UU tersebut bahwa perpustakaan merupakan institusi pengelola karya tulis, karya cetak, dan karya rekam secara profesional dengan sistem yang baku guna memenuhi kebutuhan pendidikan, penelitian, pelestarian, informasi, dan rekreasi para pemustaka. Dalam konteks ini, terdapat dua makna pada perpustakaan yakni institusi, atau tempat yang mengoleksi informasi secara profesional. Terakhir kepustakawanan dapat dimaknai sebagai yang menumbuhkan sekaligus menjadi hasil (tujuan) kesempurnaan pustakawan dalam mengelola perpustakaan (Indonesia, 2007).

\section{PEMBAHASAN}

\section{Belief, Inquiry, and Meaning dalam Elemen Dialog Dunia Kepustakawanan}

Jika dilihat secara seksama, baik dari segi teori dan praksis, maka terdapat relevansi antara paradigma filsafat kontemporer dengan lingkup kegiatan kepustakawanan. Mengacu pada ketiga konsep filsafat kontemporer di atas (Belief, Inquiry, and Meaning), penulis mencoba mengintegrasiinterkoneksikan konsepsi tersebut pada level praksis kepustakawanan melalui analisis dari masing-masing teori kemudian merekonstruksinya, sehingga dapat dilihat secara gamblang letak titik temu konsepsi tersebut melalui penjabaran masingmasing elemen dialog teori seperti di bawah ini.

Gambar 1 menunjukkan bahwa elemen dialog teori filsafat kontemporer pada tataran konsep keyakinan (belief) diawali ketika kebenaran 
ditemukan melalui sebuah informasi yang diperoleh dari pengetahuan. Sedangkan pengetahuan dalam konteks perpustakaan, merupakan serangkaian hasil dari proses simbolisasi atau kodefikasi infomasi yang dikemas kemudian disebarluaskan, sehingga dapat disimpulkan bahwa terdapat integrasiinterkoneksi elemen dialog filsafat kontemporer dengan elemen dialog praksis kepustakawanan tataran konsep Keyakinan (Belief) ditemukan titik temu pada elemen pengetahuan lewat jalur informasi.

\section{Integrasi-interkoneksi elemen dialog teori Filsafat Kontemporer pada tataran konsep Keyakinan (belief) dengan elemen dialog praksis kepustakawanan.}

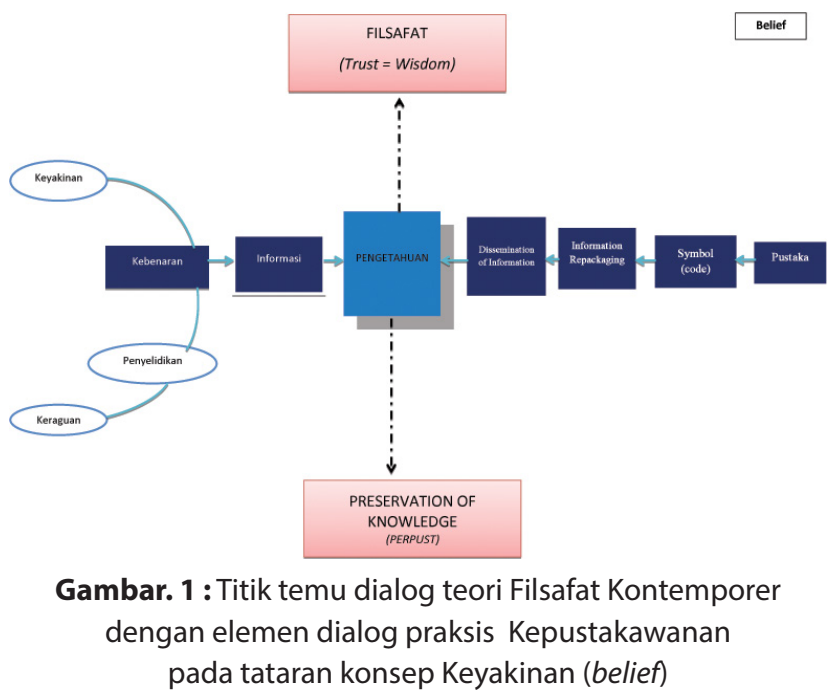

2. Integrasi-interkoneksi elemen dialog teori Filsafat Kontemporer pada tataran konsep Penyelidikan/Investigasi (Inquiry) dengan elemen dialog praksis kepustakawanan.

Gambar 2 menunjukkan bahwa elemen dialog teori filsafat kontemporer pada tataran konsep konsep Penyelidikan/Investigasi (Inquiry) dapat dilihat secara gamblang bahwa kegiatan investigasi atau penyelidikan diawali dengan adanya faktor keraguan pada diri seseorang, sehingga kegiatan atau tindakan tersebut ditempuh dengan melalui mengkaji sebuat tulisan (sumber-sumber informasi tertulis/tercetak) atau dengan pengalaman seseorang. Prosesi tersebut nantinya akan membentuk sebuah perilaku bagi seseorang dalam melakukan investigasi atau mencari ataupun menelusur sebuah informasi. Sedangkan informasi dalam konteks perpustakaan, merupakan serangkaian berbagai informasi yang telah dikodefikasi sesuai subjeknya kemudian disimpan dalam suatu "wadah" (baik berupa web server ataupun bank data yang berisi informasi yang siap diakses dan ditemu-kembalikan di perpustakaan) untuk memudahkan proses temu kembali informasi tersebut. Dari rangkaian praksis kepustakawanan tersebut, juga membentuk prilaku yang berbeda-beda bagi kalangan "pemustaka" ketika mencari dan menelusur informasi di perpustakaan. Dari rangkaian tersebut, dapat disimpulkan bahwa terdapat integrasi-interkoneksi elemen dialog filsafat kontemporer dengan elemen dialog praksis kepustakawanan tataran konsep Penyelidikan/Investigasi (Inquiry) ditemukan titik temu pada elemen informasi lewat jalur perilaku.

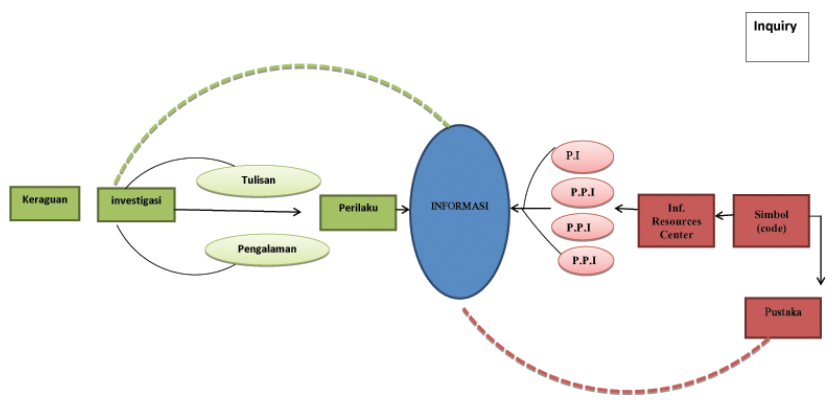

*Keterangan:

P.I = Perilaku Informasi (Information Behavior)

P.P.I = Perilaku Penemuan Informasi (Information Seeking Behavior)

P.P.I = Perilaku Pencarian Informasi (Information Searching Behavior)

P.P.I = Perilaku Penggunaan Informasi (Information Use Behavior)

Gambar. 2: Titik temu dialog teori Filsafat Kontemporer 
Belief, Inquiry, and Meaning: Integrasi-Interkoneksi ... (Mukhlis)

dengan elemen dialog praksis Kepustakawanan Pada tataran konsep Penyelidikan/Investigasi (Inquiry)

3. Integrasi-interkoneksi elemen dialog Filsafat Kontemporer pada tataran konsep makna (Meaning) dengan elemen dialog praksis kepustakawanan.

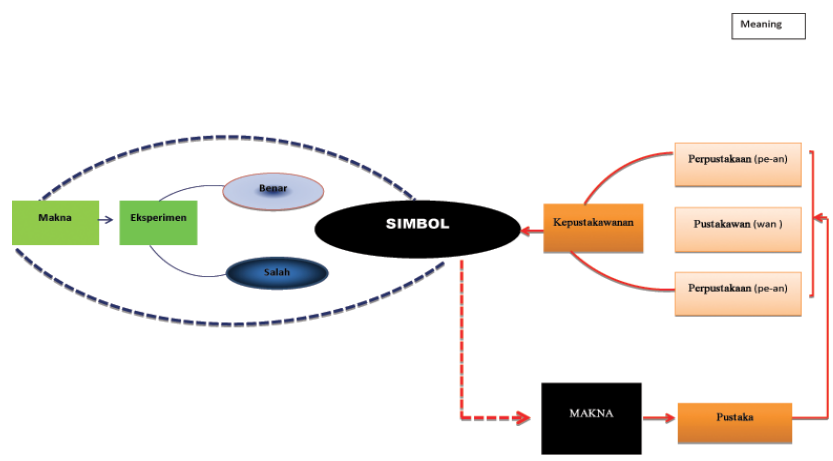

Gambar. 3: Titik temu dialog teori Filsafat Kontemporer dengan elemen dialog praksis Kepustakawanan

Pada tataran konsep makna (Meaning)

Gambar 3 menunjukkan bahwa elemen dialog teori filsafat kontemporer pada tataran konsep Makna (Meaning) dapat dilihat secara gamblang bahwa makna diperoleh dengan cara eksperimental untuk menemukan benar atau salah terhadap sesuatu, sehingga hasil temuan atau pemaknaan sesuatu tersebut kemudian dilontarkan sebuah simbol sebagai bentuk pemaknaan terhadap sesuatu. Sedangkan makna dalam konteks kepustakawanan yakni makna dari pustaka yang mendapat afiks (imbuhan). Dari rangkaian kata tersebut (pustaka) kemudian terdapat tiga pecahan kata yang masing-masing mendapatkan afiks. Masing-masing kata yang memiliki makna yang berbeda kemudian melekat sebuah simbol yang memiliki makna yang berbeda. Dari rangkaian tersebut, dapat disimpulkan bahwa terdapat integrasi-interkoneksi elemen dialog filsafat kontemporer dengan elemen dialog praksis kepustakawanan tataran konsep Makna (Meaning), sehingga ditemukan titik temu dialog pada elemen simbol, yang sama-sama melahirkan sebuah makna yang menjadi ciri khas keilmuan masing-masing.

\section{Akumulasi Integrasi-interkoneksi elemen dialog Filsafat Kontemporer dengan elemen dialog praksis kepustakawanan.}

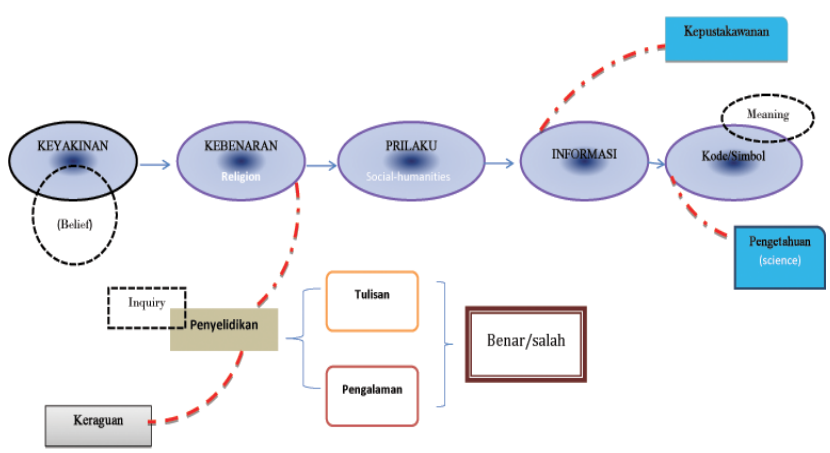

Gambar. 4: Integrasi-interkoneksi elemen dialog Filsafat Kontemporer dengan elemen dialog praksis kepustakawanan

Gambar 4 menunjukkan bahwa elemen teori filasat kontemporer yang terkait dengan tiga konsep utama (Belief, Inquiry, and Meaning) mampu berdialog (berkomunikasi; bertuegur-sapa) dengan elemen dialog kepustakawanan khususnya pada tataran praksis. Dialog tersebut ditemukan pada titik temu pada elemen informasi yang bermuara pada pengetahuan (science). Temuan ini membuktikan asumsi dasar penulis di awal, bahwa terdapat keterkaitan titik temu pada konsepsi tersebut melalui penjabaran masing-masing elemen dialog teori yang dilihat dari level praksis. Benang merah dari temuan ini, bahwa dinamika atau dinamisasi teori disebabkan oleh faktor pengetahuan (science) yang dimunculkan dari dan oleh manusia itu sendiri yang memiliki keyakinan (belief) dalam hal mencari, dan menginvestigasi (inquiry) sehingga membentuk sebuah perilaku, baik individu maupun sosial (social-humanities) terhadap suatu informasi yang telah dikodefikasi atau telah disimbolisasi oleh disiplin ilmu kepustakawanan menjadi sebuah 
pengetahuan (science).

\section{SIMPULAN}

Dinamika kehidupan disebabkan oleh faktor pengetahuan (science) yang dimunculkan dari dan oleh manusia itu sendiri, sehingga kedudukan manusia sebagai individu dan anggota masyarakat (social-humanities) dalam satu struktur kesatuan yang senada dalam konsepsi agama (religion). Dengan demikian manusia adalah makhluk individu yang memasyarakat sekaligus makhluk sosial yang mengindividu. Kesadaran akan perlunya integrasiinterkoneksi antara ilmu pengetahuan (science), dengan nilai-nilai moral (social-humanities), dan agama (religion) akan muncul manakala manusia semakin sadar bahwa ilmu pengetahuan tidak dapat berdiri/berjalan sendiri sehingga salah satu teori filasat kontemporer yang relevan dengan hal tersebut yakni tiga konsep utama (Belief, Inquiry, and Meaning).

Situasi tersebut berkorelasi dengan kegiatan kepustakawanan, karena hal tersebut menyangkut dua hal, yakni mengelola informasi menjadi pengetahuan, serta kemampuan untuk melayankannya kepada para pemustaka. Hal ini lah yang nantianya akan digiring ke arah action dan praxis. Lalu bagaimana jika mengintegrasiinterkoneksikan elemen dialog filsafat kontemporer dengan elemen dialog praksis kepustakawanan? dimana letak titik temunya?, hal ini telah dibuktikan dengan sebuah temuan bahwa dialog teori ditemukan pada titik temu dari elemen informasi yang bermuara pada pengetahuan (science) yang telah dikodefikasi atau telah disimbolisasi oleh disiplin ilmu kepustakawanan.

\section{DAFTAR PUSTAKA}

Choir, T. (2009). Islam Dalam Berbagai Pembacaan Kontemporer (A. Fanani, Ed.). Yogyakarta: Pustaka Pelajar.

Indonesia, D. P. N. (2007). Undang-undang Republik
Indonesia Tentang Perpustakaan Nomor 43 Tahun 2007. Jakarta: Departemen Pendidikan Nasional.

Khuza'i, R. (2007). Dialog Epistemologi Mohammad lqbal dan Charles S Peirce. Bandung: Refika Aditama.

Marzano, R. J. (2000). Designing a new taxonomy of educational objectives. Retrieved February 24, 2016, from Thousand Oaks, CA: Corwin Press website: http://www.intel.co.id/ content/dam/www/program/education/ apac/id/id/documents/project-design/skills/ id-project-design-thinking-skills-higherthinking-using-knowledge.pdf

Munitz, M. K. (1981). Contemporary Analytic Philosophy. London: Collier Macmillan Publishers.

Pendit, P. L. (2003). Penelitian Ilmu Perpustakaan dan Informasi: suatu pengantar diskusi epistemologi dan metodologi. Jakarta: JIP-FSUI.

Pendit, P. L. (2014). Dari Pustaka sampai Informatika: Kesinambungan Peran Pustakawan \& Profesi informasi di Masyarakatnya. Seminar Nasional ISIPII 2014. Depok: Universitas Indonesia.

Soetriyono. (2007). Filsafat IImu dan Metodologi Penelitian. Yogyakarta: Andi.

Sudarsono, B. (2013). Filsafat Kepustakawanan. Retrieved February 24, 2019, from https:// pustakapusdokinfo.files.wordpress. com/2013/09/filsafatkepustakawanan1.pdf

Wilson, T. . (2000). Human Information Behavior. Informing Science: The International Journal of an Emerging Transdiscipline, 3(2).

Yusuf, P. M. dan P. S. (2010). Teori \& Praktik Penelusuran Informasi: Information Retrieval. Jakarta: Kencana. 